\title{
Wizyty Zygmunta Starego w Toruniu (1519-1521)
}

Sylwia Dwojak

Toruń

Elekcja kolejnego z Jagiellonów, Zygmunta Starego, na króla Polski nastąpiła 8 grudnia $1506 \mathrm{r}^{1}{ }^{1} \mathrm{~W}$ stosunkach z państwem krzyżackim od samego początku władca ten podtrzymywał twardy kurs wobec opornego wielkiego mistrza Fryderyka Saskiego, przez co ten 31 marca 1507 r. opuścił Prusy i udał się do Rzeszy, szukając sojuszników w konflikcie z polskim monarchą ${ }^{2}$. Jego śmierć w 1510 r. i wybór nowego zwierzchnika Zakonu, Albrechta Hohenzollerna, odsunęły na kilka lat wybuch wojny polsko-krzyżackiej ${ }^{3}$. Z powodu ciągłych walk Wielkiego Księstwa Litewskiego z Moskwą (między innymi w latach 1507-1508), a także najazdu Tatarów na Królestwo Polskie dopiero po dłuższym czasie król mógł udać się do Prus (1519), by ostatecznie podjąć próbę rozwiązania konfliktu z wielkim mistrzem.

\footnotetext{
${ }^{1}$ M. Biskup, Polska a zakon krzyżacki w Prusach w początkach XVI w. U źródel sekularyzacji Prus Krzyżackich, Olsztyn 1983, s. 197.

${ }^{2}$ Ibid., s. 209.

${ }^{3}$ Nowy wielki mistrz i jednocześnie siostrzeniec (syn Zofii Jagiellonki, siostry Zygmunta Starego) polskiego króla Albrecht Hohenzollern przygotowania do wojny z Polską rozpoczął w 1516 r., zarządzając między innymi przegląd gotowości bojowej zamków i zbrojnych pruskich. Od połowy 1517 r. szukał również sprzymierzeńców przeciwko Polsce na terenie Rzeszy - por. J. Wijaczka, Albrecht von BrandenburgAnsbach (1490-1568). Ostatni mistrz zakonu krzyżackiego i pierwszy ksiązę w „Prusiech”, Olsztyn 2010, s. 54.
} 
Przez pierwsze lata panowania Zygmunta Starego, zanim władca przybył do Torunia osobiście, podejmowano próby zakończenia sporu z Albrechtem Hohenzollernem na drodze polubownej, ale bez rezultatu, co w konsekwencji doprowadziło do wybuchu wojny polsko-krzyżackiej ${ }^{4}$. W jej początkowej fazie król przebywał w Toruniu nieprzerwanie przez wiele miesięcy ( $\mathrm{w}$ tym czasie $\mathrm{w}$ mieście zorganizowano dwa zjazdy stanów pruskich), i to właśnie związane z tym wydarzenia są przedmiotem niniejszej analizy.

\section{Wojna polsko-krzyżacka. Toruń jako kwatera główna Zygmunta Starego (1519)}

Wielki mistrz zakonu krzyżackiego, mimo wyraźnych ustępstw ze strony Zygmunta Starego, parł do wojny. Już w liście $\mathrm{z}$ dnia 21 września 1519 r. do biskupa warmińskiego Fabiana Luzjańskiego monarcha informował dostojnika kościelnego, że z Niemiec wyruszyło około 10 tysięcy zaciężnych krzyżackich i część z nich, zmierzając do Prus, ma przejść przez terytorium Królestwa Polskiego ${ }^{5}$. Podobną wiadomość przekazał dzień później biskup chełmiński Jan Konopacki Radzie Miasta Gdańska i dodał, że rajcy powinni się zwrócić do monarchy o zwołanie jak najprędzej zjazdu stanów ${ }^{6}$. W związku z groźbą ataku owych zaciężnych na Prusy Królewskie polski władca postanowił na wszelki wypadek przygotować się do obrony i wydał rozkaz, aby wysłać do Prus kilkuset zaciężnych, których władze Torunia miały w razie potrzeby przewieźć statkami wiślanymi ${ }^{7}$.

Jak się okazało, polski władca także pragnął zwołania zjazdu stanów pruskich $\mathrm{w}$ celu zasięgnięcia rady $\mathrm{w}$ kwestii wojny $\mathrm{z}$ wielkim mistrzem, o czym wiemy z relacji hetmana Kościeleckiego, wojewody

${ }^{4}$ J. Małłek, Ostatni Jagiellonowie: Zygmunt Stary i Zygmunt August, [w:] Królowie polscy, red. M. Biskup, Torun 1984, s. 25.

${ }^{5}$ Akta Stanów Prus Królewskich (1516-1520), wyd. I. Janosz-Biskupowa, M. Biskup, t. 7, Warszawa-Poznań-Toruń 1986, nr 126 (dalej: ASPK, t. 7).

${ }^{6}$ Ibid., nr 127.

${ }^{7}$ M. Biskup, U schyłku średniowiecza $i$ w początkach odrodzenia (1454-1548), [w:] Historia Torunia, red. M. Biskup, t. 2, cz. 1, Torun 1992, s. 181. 
malborskiego Jerzego Bażyńskiego i wojewody pomorskiego Jerzego Konopackiego przesłanej gdańskiej Radzie. Po otrzymaniu tychże doniesień postanowiła ona, że wraz z biskupem Fabianem Luzjańskim zadecyduje o terminie i miejscu zjazdu ${ }^{8}$. Jednak uprzedził ich $w$ tym Zygmunt I, który w liście z Krakowa z dnia 16 października 1519 r. postanowił, że sejm walny zbierze się w Toruniu'. Główny przedmiot obrad miała stanowić kwestia walki zbrojnej z zakonem krzyżackim ${ }^{10}$. Początek sejmu wyznaczono na 25 listopada 1519 r. Mieli wziąć w nim udział zarówno dostojnicy polscy, jak i pruscy ${ }^{11}$. Poza poinformowaniem o terminie zjazdu monarcha wyraził również wdzięczność gdańskiej Radzie za wysiłki, jakie podjęła ona, starając się przeciwdziałać zagrożeniu Prus ze strony Zakonu ${ }^{12}$. Przebywający w Malborku hetman Stanisław Kościelecki 22 października poinformował władze Gdańska o planach przyjazdu Zygmunta Starego do Torunia około 19 listopada ${ }^{13}$. Ci zaś dzień później przekazali mu wiadomość o przybyciu do miasta zaciężnych królewskich. Prosili go, aby zadecydował o rozmieszczeniu ich na zamkach ${ }^{14}$.

Król nie przybył do miasta w wyznaczonym terminie 25 listopada 1519 r., tylko z tygodniowym opóźnieniem, 2 grudnia. Dzień przed przyjazdem do Torunia nocował w Służewie (ówczesnym miasteczku na Kujawach), gdzie nastąpiło pierwsze oficjalne powitanie władcy przez przedstawicieli prowincji Prus Królewskich. Wśród witających znajdowali się między innymi wojewoda pomorski Jerzy Konopacki,

\footnotetext{
${ }^{8} \mathrm{~W}$ źródle informowano, że jeśli nie byłoby możliwe jego zwołanie, to poszczególni radcy mieli listownie doradzić królowi, jak powinien tę wojnę przeprowadzić. Wystawcy pisma informowali również o konieczności wprowadzenia podatku dla mieszkańców wsi wraz z sołtysami w celu uzyskania środków na cele wojenne-ASPK, t. 7, nr 134.

${ }^{9}$ Ibid., nr 137.

${ }^{10}$ Decyzję o rozpoczęciu wojny z Krzyżakami Zygmunt Stary podjął już 12 października 1519 r. po naradach z wielkopolskimi i małopolskimi możnowładcami. Tego samego dnia polski król mianował na dowódcę armii wojewodę sandomierskiego Mikołaja Firleja z Dąbrownicy - J. Wijaczka, Albrecht von Brandenburg-Ansbach, s. 58.

${ }^{11}$ M. Biskup, Polska a zakon krzyżacki, s. 579.

${ }^{12}$ ASPK, t. 7, nr 137

${ }^{13}$ Ibid., nr 140 .

${ }^{14}$ Ibid., nr 141
} 
podkomorzy malborski Achacy Cema, burmistrzowie toruński Konrad Hitfeld oraz gdański Eberhard Ferber, którzy przybyli na spotkanie w towarzystwie stu konnych ${ }^{15}$. Król dotarł do Torunia wraz ze swym orszakiem, w którego skład wchodzili dostojnicy królewscy oraz 1500 konnych. Na lewym brzegu Wisły nastąpiło kolejne powitanie. Kiedy władca dotarł do drewnianego mostu, naprzeciw niego wyszli świeccy i duchowni pruscy dygnitarze ${ }^{16}$. Poza nimi w uroczystości uczestniczyli także uczniowie $\mathrm{z}$ miejscowych szkó ${ }^{17}$. Potem na moście nastąpiło kolejne, trzecie już powitanie. Przemówienie w imieniu wszystkich dostojników pruskich wygłosił po łacinie biskup warmiński Fabian Luzjański ${ }^{18}$. W swoim orędziu zawarł między innymi skargi na zakon krzyżacki. Wspomniał o morderstwach, napadach rabunkowych, podpaleniach i innych krzywdach, jakich doznają mieszkańcy prowincji pruskiej od Krzyżaków ${ }^{19}$. Odpowiedzi w imieniu króla udzielił biskup przemyski i podkanclerzy koronny Piotr Tomicki, ale reces zjazdu nie wspomina, w jakim języku została ona udzielona. Jak wynika $\mathrm{z}$ owego przekazu, król zapewnił, że zadba o swoich pruskich poddanych i nie opuści ich, skoro znajdują się w niebezpieczeństwie ${ }^{20}$. Ponieważ była w tym czasie brzydka pogoda, senatorów Królestwa Polskiego nie witano już każdego z osobna tylko ruszono dalej w drogę prowadzącą przez most. Po jego przejściu monarcha odebrał kolejne honory, tym razem od toruńskiej Rady, ławników oraz pozostałych mieszkańców miasta. Uroczystość ta odbyła się przy Bramie Żeglarskiej, przez którą polscy władcy mieli zwyczaj wjeżdżać do miasta. W czasie jej trwania przemówienie wygłosił drugi burmistrz Torunia Mikołaj Friedwald.

${ }^{15}$ Thorner Denkwürdigkeiten von 1345-1547, hrsg. v. A. Voigt, Mitteilungen des Coppernicus-Vereins für Wissenschaft und Kunst zu Thorn, 13 (1904), s. 149 (dalej: Thorner Denkwürdigkeiten).

${ }^{16}$ J. Małłek, Ostatni Jagiellonowie, s. 25; Fortsetzung der Danziger Chronik. Bernt Stegmann's Hanseatische Chronik, hrsg v. T. Hirsch, [w:] Scriptores Rerum Prussicarum. Die Geschichtsquellen der preussischen Vorzeit bis zum Untergange der Ordensherrschaft, hrsg. v. T. Hirsch, M. Töppen und E. Strehlke, Bd. 5, Leipzig 1871, s. 505-506.

${ }^{17}$ ASPK, t. 7, nr 148, s. 357-359.

${ }^{18}$ Thorner Denkwürdigkeiten, s. 149.

${ }^{19}$ J. Małłek, Ostatni Jagiellonowie, s. 25-26.

${ }^{20}$ ASPK, t. 7, nr 148, s. 358 
Po jego zakończeniu i po podziękowaniu przez króla za serdeczne przyjęcie, Zygmunt Stary pod baldachimem, w towarzystwie dwóch radców pruskich i dwóch burmistrzów Torunia (Jakuba Seusse i Konrada Hitfelda), udał się do kościoła Świętych Janów, gdzie, podobnie jak inni Jagiellonowie podczas swoich pobytów w Toruniu, uczestniczył w nabożeństwie, w czasie którego odśpiewano „Te Deum Laudamus". Podczas mszy polski władca złożył ofiarę, której wysokość wynosiła 9 florenów węgierskich. Po zakończeniu nabożeństwa odprowadzono władcę do Ratusza Staromiejskiego, gdzie zatrzymał się z przerwami na kilkanaście tygodni ${ }^{21}$. Liczni dostojnicy królewscy (na czele z arcybiskupem Łaskim, kanclerzem Krzysztofem Szydłowieckim i podkanclerzym Piotrem Tomickim) zatrzymali się w prywatnych gospodach lub klasztorach. Natomiast w mieście i na przedmieściach w prywatnych domach ulokowane zostały oddziały nadworne ${ }^{22}$.

Nie wiadomo, co król robił dzień po przyjeździe. Kolejne informacje na temat jego poczynań pochodzą z 4 grudnia. W recesie zapisano, iż brał udział w nabożeństwie ku czci św. Ducha. Poza władcą uczestniczyli w nim również radcy koronni i pruscy. Dzień później (5 grudnia) w toruńskim ratuszu rozpoczęły się rozmowy monarchy z dostojnikami Królestwa Polskiego i Prus Królewskich. Obrady dotyczyły podjęcia decyzji w sprawie sposobu prowadzenia wojny $\mathrm{z}$ zakonem krzyżackim. Rozmowy rozpoczęły się od przedstawienia, w imieniu króla, przez podkanclerzego i biskupa przemyskiego Piotra Tomickiego wysiłków, jakie podjął Zygmunt Stary w celu zakończenia konfliktu drogą pokojową. Mówca zaznaczył, że mimo problemów, z jakimi boryka się Królestwo Polskie ze strony Tatarów i Moskwy, władca przybył do Torunia, aby wraz z radcami znaleźć rozwiązanie kwestii krzyżackiej $^{23}$. Następnie biskup Luzjański oddał głos panom koronnym jako starszym i dostojniejszym od pruskich. W ich imieniu mowę wygłosił arcybiskup gnieźnieński Jan Łaski. On również przedstawił nieudane próby rokowań, jakie podejmowano w celu rozwiązania sporu ze zwierzchnikiem Zakonu, a następnie zaprezentował historyczne

${ }^{21}$ ASPK, t. 7, nr 148, s. 359; Thorner Denkwürdigkeiten, s. 149.

${ }^{22}$ M. Biskup, U schytku średniowiecza, s. 182.

${ }^{23}$ ASPK, t. 7, nr 148, s. 360-361. 
prawa Polski do Prus ${ }^{24}$. Zgromadzeni w ratuszu dostojnicy królewscy i pruscy zgodnie popierali walkę zbrojną, twierdzili bowiem, że „lepsza dobra wojna niż zły pokój" 25 , a skoro wszelkie próby pokojowe zawiodły, zostaje już tylko rozwiązanie konfliktu na drodze działań militarnych. Jan Łaski stwierdził również, że najlepiej powodziło się Polsce wtedy, kiedy stosowała wobec Zakonu przemoc, natomiast traktaty pokojowe zawsze przynosiły szkodę ${ }^{26}$. Arcybiskup gnieźnieński przedstawił też jeszcze inny pomysł, a mianowicie możliwość całkowitego usunięcia Zakonu z Prus i przeniesienia go gdzieś na południowe obszary kontynentu europejskiego. Po przemówieniu dostojnika kościelnego głos zabrali przedstawiciele Gdańska. Na samym początku podziękowali władcy za pomoc finansową, ofiarowaną przez niego ich miastu, a także za przysłanie w celu wzmocnienia obrony Gdańska świetnego dowódcy wojskowego - Mikołaja Storcza. Później posłowie tegoż miasta radzili polskiemu królowi, aby zwrócił uwagę na niebezpieczeństwo zagrażające Polsce z powodu kontaktów wielkiego mistrza z innymi władcami, między innymi z królem Danii Chrystianem II czy z Brandenburgią. Doradzali mu również, aby nawiązał stosunki z władcami przychylnymi Królestwu Polskiemu, a mianowicie z księciem pomorskim Bogusławem X oraz z gubernatorem Szwecji Stenem Sture młodszym. Następnie podczas toruńskiego spotkania przemówił sam Zygmunt, który uważał, że sprawa z zakonem krzyżackim powinna zostać rozstrzygnięta mieczem. Dodał również, że doświadczenie uczy, iż wojny są kosztowne, więc trzeba przeprowadzić dyskusje nad środkami finansowymi i z tego powodu podjęcie decyzji $\mathrm{w}$ tej sprawie odroczył do 6 grudnia $^{27}$.

Zgodnie z zapowiedziami, tego samego dnia odbyła się w ratuszu kolejna narada Zygmunta I w ścisłym gronie radców Królestwa Polskiego i Prus Królewskich. Tematem obrad było zapewnienie władcy pomocy finansowej na prowadzenie wojny z zakonem krzyżackim. Radcy koronni zapewnili króla, że poświęcą swoje życie i całe swoje

\footnotetext{
${ }^{24}$ Ibid., s. 363.

${ }^{25}$ M. Biskup, ,,Wojna Pruska” czyli walka Polski z zakonem krzyżackim z lat 15191521, Olsztyn 1991, s. 80.

${ }^{26}$ M. Biskup, Polska a zakon krzyżacki, s. 592-593.

${ }^{27}$ ASPK, t. 7, nr 148, s. 363-366.
} 
mienie, aby go wspomóc. Pruscy biskupi zaproponowali przekazanie na ten cel połowy dochodów ze swoich biskupstw. Z kolei wojewodowie oraz Toruń i Elbląg nie zadeklarowali konkretnych sum, lecz obiecali tyle, ile w chwili wybuchu wojny będą mogli wyłożyć lub tyle, ile nakażą im w wydanej uchwale stany pruskie. Na koniec rozmów prowadzonych tego dnia poselstwo gdańskie zapewniło Zygmunta Starego o pełnym poparciu dla jego działań ze strony Rady miasta i ogółu mieszkańców Gdańska ${ }^{28}$.

Relacja posłów gdańskich o kolejnych kilkunastu dniach pobytu króla Zygmunta w Toruniu informuje między innymi o tym, kto zawitał do miasta, by spotkać się z polskim monarchą ${ }^{29}$. Dnia 8 grudnia przyjechał dowódca wojsk królewskich hetman Mikołaj Firlej z Dąbrowicy, który za ponad dwa tygodnie (22 grudnia) miał wyruszyć z Torunia na wyprawę przeciwko wielkiemu mistrzowi ${ }^{30}$. Poza nim w tym okresie do miasta zawitali także książę mazowiecki Stanisław (21 grudnia), a dzień później zaciągnięci przez króla konni, wśród których większość stanowili zaciężni czescy ${ }^{31}$. Do Torunia dotarły też oddziały z Mazowsza, Śląska, a także hufce nadworne, również z Litwy ${ }^{32}$. Wojska te przybyły w liczbie około 10-12 tysięcy i zostały rozlokowane w różnych punktach na Kujawach, gdzie miały stacjonować do momentu rozpoczęcia działań zbrojnych ${ }^{33}$.

W tym czasie władca zmuszony był rozwiązać kilka sporów wewnętrznych. Przyjmowani na audiencjach u króla dostojnicy z Królestwa Polskiego przedkładali np. skargi przysięgłych z Wielkich Żuław na Gdańsk za to, że ten nie dostarczył drewna z Mierzei Wiślanej w celu umacniania grobli. Po staraniach posłów gdańskich zmierzających do odroczenia decyzji w tej sprawie król obiecał rozwiązać ten problem 6 stycznia 1520 r. Zygmunt Stary podjął za to decyzję w kwestii sprze-

\footnotetext{
${ }^{28}$ Ibid., s. 366-368.

${ }^{29}$ Ibid., s. 368-370.

${ }^{30}$ Wyruszył z Torunia na czele oddziałów zaciężnych, które w liczbie około 7 tysięcy zgromadziły się pod miastem na wezwanie króla polskiego w połowie grudnia 1519 r. - por. J. Wijaczka, Albrecht von Brandenburg-Ansbach, s. 60-61.

${ }^{31}$ ASPK, t. 7, nr 148, s. 368-370.

${ }^{32}$ M. Biskup, U schytku średniowiecza, s. 182.

${ }^{33}$ J. Małłek, Ostatni Jagiellonowie, s. 26.
} 
daży zboża przez chłopów z Wielkich Żuław. Nakazał im, aby handlowali nim tylko w Malborku, Elblągu bądź Gdańsku ${ }^{34}$. Ponadto 21 grudnia Zygmunt Stary wystawił dokument, w którym nadawał burmistrzowi i burgrabiemu toruńskiemu Konradowi Hitfeldowi wieś Kowróz; w 1485 r. ówczesny polski król Kazimierz Jagiellończyk nadał ją plebanowi kościoła Świętych Janów w Toruniu na 30 lat, zastrzegając, iż nadanie nabierze ważności po śmierci aktualnego plebana, kanonika chełmińskiego Rafała Waynera ${ }^{35}$.

Dnia 24 grudnia 1519 r. Zygmunt Stary przyjął na audiencji starostę brodnickiego Mikołaja Działyńskiego, który w imieniu szlachty chełmińskiej i malborskiej przedstawił władcy jej postulaty. Król cierpliwie wysłuchał żądań szlachty, a także skarg na nią małych miast (które zarzucały panom rujnowanie handlu i warzenie oraz wyszynk piwa), jednak ich załatwienie odroczył na późniejszy termin. Stwierdził, że najważniejsze jest zapewnienie odpowiedniej pomocy finansowej na coraz bliższą wojnę z zakonem krzyżackim ${ }^{36}$.

$\mathrm{W}$ związku z akcentowaniem przez polskiego władcę ogromu wydatków wojennych, jakie czekały kraj w związku ze zbliżającą się wojną, podczas kolejnych narad $\mathrm{w}$ Toruniu ponownie podjęto temat pomocy finansowej dla króla ${ }^{37}$. Monarcha zaakceptował projekt nałożenia nowego podatku na towary wywożone z kraju i domagał się jak najszybszego nałożenia tego cła, natomiast przeciwko jego wprowadzeniu ostro wystąpili posłowie gdańscy. Potępił ich za to podkanclerzy Tomicki, ale po wyjaśnieniach, dlaczego tak postąpili, stanął po ich stronie ${ }^{38}$. Ostatecznie wysokie podatki dostojnicy koronni uchwalili 23 grudnia 1519 r., a pruscy - 26 grudnia.

\footnotetext{
${ }^{34}$ ASPK, t. 7, nr 148, s. 369 .

${ }^{35}$ Katalog dokumentów i listów krzyżackich z Archiwum Państwowego w Toruniu (1345-1789), red. A. Radzimiński, J. Tandecki, Warszawa 1999, nr 227 (dalej: Katalog dokumentów).

${ }^{36}$ ASPK, t. 7, nr 148, s. 372-373.

${ }^{37}$ Stany Pruskie zadeklarowały, że przeznaczą dla władcy podatek z posiadłości ziemskich i folwarków w wysokości połowy czynszu $\mathrm{z}$ łana, a miasta zaproponowały podatek w wysokości 3 fenigów od grzywny majątku. W związku z tym, iż monarcha uważał te sumy za niewystarczające, stany pruskie rozważały możliwość nałożenia podatku na towary wywożone z kraju - ibid., s. 373.

${ }^{38}$ Ibid., s. 374-376.
} 
Ponadto szlachta z Królestwa Polskiego przeforsowała jeszcze 7 stycznia 1520 r. wydanie tzw. Statutów toruńskich, które zapewniały jej swobodę spławu Wisłą z pominięciem (na 10 lat) prawa składu Torunia. Statuty te nakazywały również ogółowi kmieci jednodniową pracę pańszczyźnianą $\mathrm{w}$ tygodniu ${ }^{39}$.

W tym samym czasie król zadecydował o rozpoczęciu walki zbrojnej z Zakonem ${ }^{40}$. Dnia 29 grudnia 1519 r. z Torunia zostały wysłane listy wypowiednie dowódców królewskich do wielkiego mistrza i zakonu krzyżackiego ${ }^{41}$. Zygmunt Stary polecił Gdańskowi, aby nie dopuścił do dowożenia morzem zaciężnych $\mathrm{z}$ pomocą dla wielkiego mistrza $^{42}$.

Po sukcesie strony krzyżackiej w pierwszych dniach działań zbrojnych (po zajęciu przez Krzyżaków Braniewa) również Albrecht postanowił oficjalnie wypowiedzieć wojnę królowi polskiemu ${ }^{43}$. Dnia 2 stycznia 1520 r. podkanclerzy Tomicki poinformował gdańskich posłów, że ich miasto powinno na własny koszt podjąć akcje na morzu przeciwko Krzyżakom. Ci odpowiedzieli, że utrzymanie przez władze miasta okrętów wojennych jest niemożliwe. Jednak wieczorem, po ponowieniu wezwania Tomickiego, gdańscy wysłannicy obiecali, że przedłożą ten postulat do rozpatrzenia Radzie Miejskiej ${ }^{44}$. Ostatniego dnia zjazdu, 4 stycznia, podkanclerzy Tomicki przekazał radcom królewskim i samemu królowi treść przechwyconego listu, napisanego przez wielkiego mistrza i skierowanego między innymi do władcy

\footnotetext{
${ }^{39}$ M. Biskup, U schytku średniowiecza, s. 182.

${ }^{40}$ Aufzeichnungen zur Geschichte des letzten Hochmeisters, hrsg. v. M. Töppen, [w:] Scriptores Rerum Prussicarum, Bd. 5, s. 341.

${ }^{41}$ Były one spisane w języku czeskim zapewne dlatego, iż większość zaciężnych w armii Królestwa Polskiego pochodziła z Czech - ASPK, t. 7, nr 148, s. 378.

${ }^{42}$ Ibid., s. 381.

${ }^{43}$ Wielki mistrz wysłał do Zygmunta Starego list, w którym wyliczył wszystkie szkody, jakie Prusom wedle jego opinii mieli wyrządzić poprzedni władcy Polski, zwłaszcza zmuszenie Zakonu do zawarcia traktatu toruńskiego w 1466 r., na którego mocy państwo krzyżackie zostało podporządkowane Królestwu Polskiemu, mimo iż bezpośrednio podlegało papiestwu - J. Wijaczka, Albrecht von Brandenburg-Ansbach, s. 62 .

${ }^{44}$ ASPK, t. 7, nr 148, s. 383-386.
} 
Danii Chrystiana II. Głównym tematem tego pisma była pomoc dla zakonu krzyżackiego w czasie wojny z Polską ${ }^{45}$.

\section{Udział króla w zjeździe stanów pruskich (1. połowa 1520 r.)}

O tym, że władca przez cały czas przebywał w Toruniu świadczą listy nadawane przez niego $\mathrm{z}$ tego miasta oraz wystawione $\mathrm{w}$ nim akta prawodawcze, np. dokument z 9 stycznia 1520 r., w którym Zygmunt Stary, w zamian za zamek w Świeciu z połową przynależnych doń dochodów, nadał Toruniowi zamek w Bierzgłowie ze wsiami: Bierzgłowo, Łążyn, Pędzewo, Świerczyny, Wybcz, Węgorzyn, Kiełbasin, Smolno, Gronowo, Rogówko i Jedwabno oraz czynsz z Piwnic, a także młyn Pachur i młyny toruńskie ${ }^{46}$. Z kolei w innym piśmie, wystawionym 13 stycznia, polski monarcha potwierdził wszelkie prawa i przywileje miasta Dąbrówno ${ }^{47}$.

O ciągłym pobycie króla w mieście świadczy również fakt, iż to tutaj monarcha przyjmował poselstwa, przeprowadzał narady $\mathrm{z}$ radcami królewskimi i pruskimi oraz nakazywał w tym mieście stawić się jeńcom strony krzyżackiej ${ }^{48}$.

\footnotetext{
${ }^{45} \mathrm{Z}$ tego powodu Zygmunt Stary postanowił działać i nakazał posłom gdańskim, aby ich miasto zainteresowało się leżącą w strategicznym miejscu cieśniną bałgijską i zadbało o jak najlepsze jej zabezpieczenie - ibid., nr 148, s. 387-388.

${ }^{46}$ Katalog dokumentów, nr 228. Tu pojawia się jednak sprzeczność, gdyż według Mariana Biskupa dokument ten miał zostać wystawiony 6, a nie 9 stycznia - por. M. Biskup, U schytku średniowiecza, s. 182.

${ }^{47}$ Matricularum Regni Poloniae Summaria, excussis codicibus, qui in Chartophylacio Maximo Varsoviensi asservantur, wyd. T. Wierzbowski, pars 4: Sigismundi I regis tempora complectens (1507-1548), Warszawa 1910, nr 3195 (dalej: Matricularum, pars 4).

${ }^{48}$ Jeńcy ci byli zwalniani z niewoli na słowo i zobowiązani do stawienia się przed obliczem króla w Toruniu w wyznaczonym terminie, aby złożyć mu przysięgę wierności. Jeżeli warunkowo zwalniani nie dotrzymali słowa i nie stawili się w wyznaczonym miejscu, wysyłano za nimi listy gończe. Jeśli zostali złapani, można ich było zabić bez sądu. $Z$ zebranych dotychczas informacji wynika, że pochwycono co najmniej kilkunastu poddanych krzyżackich i dla przykładu dokonano na nich egzekucji - J. Tyszkiewicz, Jeńcy wojenni i dyplomacja polska $w X V-X V I$ w., [w:] Balticum. Studia $z$ dziejów polityki, gospodarki i kultury XII-XVII w., red. Z. H. Nowak, Torun 1992, s. 365.
} 
Polski władca przez cały czas czuwał nad przebiegiem wojny. W lutym 1520 r. odbyła się w Toruniu narada Zygmunta Starego z radcami królewskimi i pruskimi, podczas której podjęto decyzję, aby podwoić polską armię, dosyłając jej przybyłe z opóźnieniem kolejne oddziały zaciężnych z Czech. Miały one wspomóc walczących podczas planowanego oblężenia Kwidzyna, a później Pasłęka ${ }^{49}$. Mimo kończących się królowi pieniędzy na prowadzenie wojny z zakonem krzyżackim, Zygmunt nie przerywał akcji militarnej. Ponadto 19 lutego w toruńskim ratuszu wydał edykt, w którym zabronił swoim poddanym, przede wszystkim z miast Prus Królewskich, handlowania z państwem krzyżackim. Jeszcze tego samego dnia nakazał również ściągnąć z Krakowa do Torunia działa dla polskiej armii ${ }^{50}$.

W czasie prowadzonych działań militarnych Zygmunt Stary przyjmował w Toruniu liczne poselstwa. Jako pierwsi, w drugiej połowie lutego 1520 r., zjawili się wysłannicy papieża Leona X, a mianowicie legat biskup gardeński Zachariasz Ferreri Guadalfieri i florentyńczyk Jan Thedaldi ${ }^{51}$. Kolejne delegacje zostały wysłane przez księcia saskiego Jerzego Bogatego (szwagra Zygmunta Starego) i trzech elektorów Rzeszy (ci przybyli około 10 kwietnia) oraz króla węgierskiego i czeskiego Ludwika Jagiellończyka ${ }^{52}$. Ich celem było doprowadzenie do pokoju pomiędzy Polską a zakonem krzyżackim. W związku z ich licznym przybywaniem do miasta władca postanowił zwołać zjazd. W liście nadanym w Toruniu dnia 7 maja wzywał między innymi Radę Miasta Gdańska do przysłania swoich przedstawicieli najpóźniej do 13 maja $1520 \mathrm{r}^{53}$ Rada postąpiła zgodnie z rozkazem króla i wysłała do Torunia dwóch swoich posłów - burmistrza Henryka Wise i rajcę Reinholda Feldstete ${ }^{54}$.

Zgodnie z postanowieniem Zygmunta I, dnia 13 maja 1520 r. rozpoczął się (trwający do 30 maja) zjazd w Toruniu z udziałem władcy,

\footnotetext{
${ }^{49}$ M. Biskup, ,Wojna Pruska”, s. 132.

${ }^{50}$ J. Wijaczka, Albrecht von Brandenburg-Ansbach, s. 62-63.

${ }^{51}$ M. Biskup, U schytku średniowiecza, s. 183.

${ }^{52}$ Ibid.

${ }^{53}$ Akta Stanów Prus Królewskich (1520-1526), wyd. I. Janosz-Biskupowa, M. Biskup, t. 8, Warszawa-Toruń 1993, nr 2 (dalej: ASPK, t. 8).

${ }^{54}$ Ibid., $\mathrm{nr} 3$.
} 
stanów pruskich, posłów zagranicznych oraz nuncjusza papieskiego Zachariasza Ferreri. Reces zjazdu informuje, że posłowie z Gdańska przybyli z opóźnieniem, 18 maja. Dzień później zostali oni wraz z pruskimi radcami przyjęci w ratuszu na audiencji u króla. Potem odbyło się spotkanie Zygmunta I z posłami książąt Rzeszy, w którym wzięli także udział gdańscy wysłannicy. W czasie jego trwania biskup przemyski i podkanclerzy koronny Piotr Tomicki stwierdził, iż to wielki mistrz jest winny niemożności dojścia do porozumienia i zawarcia pokoju. Podziękował jednak posłom saskim za wysiłki, jakie wkładają, aby móc zakończyć polsko-krzyżacki konflikt. W imieniu przybyłych posłów przemówił Dytrych Werterde, który podziękował Polakom za okazaną gościnność oraz zapewnił Zygmunta Starego o życzliwości i wsparciu ze strony księcia Jerzego. Następnego dnia kontynuowano rozmowy i rozpatrywano pomysł nuncjusza papieskiego, biskupa gardeńskiego Zachariasza Ferreri, przekazany zebranym przez wyżej wspomnianego Piotra Tomickiego. Zaproponował on, aby przysięgę wierności polskiemu władcy złożyli poddani zakonu krzyżackiego, a wielkiemu mistrzowi miała ona zostać zawieszona do jego śmierci. Propozycję tę zwierzchnikowi Zakonu mieli przedłożyć przedstawiciele Węgier i Rzeszy. Poza tym nuncjusz chciał, aby na czas rozmów $\mathrm{z}$ wielkim mistrzem Zygmunt I zgodził się na zawarcie 10-dniowego rozejmu ${ }^{55}$. Ostatecznie 22 maja, po odbyciu narady z radcami nad propozycjami poselstwa, polski monarcha wyraził na nie zgodę. Dnia 24 maja posłowie węgierscy po uroczystym pożegnaniu udali się na rozmowy z Albrechtem. Wobec oporu posłów książąt Rzeszy, którzy nie chcieli udać się do Królewca $\mathrm{z}$ tego względu, iż mógł on być już oblegany, po radach dostojników pruskich Zygmunt I odesłał ich do kraju ${ }^{56}$.

W kolejnych dniach król rozmawiał z radcami pruskimi nie tylko na temat wojny, ale również spraw wewnętrznych. Obecni posłowie

\footnotetext{
${ }^{55}$ Jak wynika z recesu, radcy koronni i pruscy doradzali władcy, aby zgodził się na takie rozwiązanie. Rozmowy jednak się nie zakończyły i nuncjusz przedkładał nowe propozycje rozstrzygnięcia konfliktu. Wraz z posłami węgierskimi 21 maja zasugerował on, aby złagodzono kilka warunków traktatu toruńskiego z 1466 r., znów przy wprowadzeniu 10-dniowego rozejmu na czas rozmów z wielkim mistrzem - ASPK, t. 8, nr 4; J. Wijaczka, Albrecht von Brandenburg-Ansbach, s. 71.

${ }^{56}$ ASPK, t. 8, nr 4; J. Wijaczka, Albrecht von Brandenburg-Ansbach, s. 71.
} 
gdańscy, zanim przeszli do poinformowania władcy o działaniach Zakonu na Bałtyku, złożyli najpierw wykaz swoich postulatów ${ }^{57}$. Dzień później (26 maja) odbyła się odrębna narada pruskich dostojników, podczas której zebrano wiele próśb i skarg, które jeszcze tego samego dnia w imieniu stanów pruskich przedstawił władcy po polsku biskup chełmiński Jan Konopacki ${ }^{58}$.

Po przerwie powrócono do rozmów dotyczących pokojowych prób zakończenia konfliktu polsko-krzyżackiego. Dnia 28 maja podczas audiencji $\mathrm{w}$ toruńskim ratuszu nuncjusz papieski Zachariasz Ferreri zrelacjonował Zygmuntowi Staremu oraz radcom pruskim rozmowy z przybyłymi do Torunia kilka dni wcześniej posłami Zakonu i stanów Prus Krzyżackich. Nuncjusz poinformował obecnych, że donieśli oni o niepowodzeniu misji pokojowych posłów książąt Rzeszy i poselstwa węgierskiego. Dodał, że wysłannicy wielkiego mistrza chcą uzyskać od polskiego monarchy glejt dla zwierzchnika Zakonu, który wyraził chęć przybycia do Torunia w celu przeprowadzenia rokowań pokojowych. Król postanowił osobiście wysłuchać ich na audiencji. Tak też się stało i podczas spotkania posłowie stanów Prus Krzyżackich, a także prokurator nidzicki Henryk von Miltitz przekazali władcy, iż z inicjatywy biskupa warmińskiego Fabiana Luzjańskiego stanom udało się namówić Albrechta Hohenzollerna do osobistego przybycia do Torunia $\mathrm{w}$ celu przeprowadzenia rokowań pokojowych. W przypadku zgody monarszej proszono o glejt dla wielkiego mistrza i na rozejm na czas prowadzenia rozmów. Król postanowił najpierw naradzić się z radcami królewskimi i pruskimi i odroczył udzielenie odpowiedzi. Owa narada odbyła się dzień później. Podczas niej dostojnicy Królestwa Polskiego i Prus doradzili władcy, aby przyjął propozycję rokowań ze zwierzchnikiem zakonu krzyżackiego. Zaproponowali też, aby rozejm trwał 14 dni. Król posłuchał ich rad i zgodził się na przybycie Albrechta do Torunia ${ }^{59}$.

\footnotetext{
${ }^{57}$ ASPK, t. 8, nr 4.

${ }^{58}$ Ibid.

${ }^{59}$ Ibid.
} 


\section{Rokowania pokojowe - część pierwsza (lato 1520 r.)}

Dnia 3 czerwca 1520 r. do przebywającego w Królewcu wielkiego mistrza dotarli reprezentanci króla oraz stanów pruskich. Przywieźli ze sobą glejt Zygmunta dla Albrechta ważny 14 dni, wystawiony na czas jego podróży do Torunia $w$ towarzystwie 200 konnych. $Z$ powodu złej sytuacji, w jakiej znajdował się zakon krzyżacki, a także nacisków na wielkiego mistrza ze strony stanów Prus Krzyżackich, ten zgodził się udać do Torunia na osobiste rozmowy z Zygmuntem Starym. Dnia 5 czerwca zwierzchnik Zakonu uzgodnił z wysłannikami króla (między innymi hetmanem Mikołajem Firlejem oraz wojewodą kaliskim Janem Zarembą) warunki dwutygodniowego rozejmu (który miał obowiązywać do 12 czerwca ${ }^{60}$. Zgodnie z zapowiedziami Albrecht Hohenzollern wyjechał do Torunia 12 czerwca $\mathrm{w}$ towarzystwie licznego orszaku ${ }^{61}$. W tym samym czasie polski władca listownie nakazał Radzie Miasta Gdańska jak najszybsze dosłanie na rokowania większej liczby przedstawicieli z ich miasta ${ }^{62}$. Zgodnie z prośbą króla, 15 czerwca $\mathrm{z}$ Gdańska wyruszyli do Torunia burmistrz gdański Eberhard Ferber, rajca Ulryk Huxer oraz sekretarz Ambroży Storm. Dotarli do miasta 18 czerwca. Tego samego dnia po południu do Torunia przybył wielki mistrz wraz ze swoją liczną świtą ${ }^{63}$. Przed wjazdem do miasta zostali oni powitani z honorami przez kilku dostojników z Królestwa Polskiego i Prus ${ }^{64}$.

Upłynęło jednak kilka dni zanim doszło do rozmów Zygmunta Starego z Albrechtem. Najpierw, dnia 19 czerwca, podczas narad w Ratuszu Staromiejskim władca zastanawiał się z radcami królewskimi i pru-

${ }^{60}$ ASPK, t. 8, nr 5; J. Wijaczka, Albrecht von Brandenburg-Ansbach, s. 66.

${ }^{61} \mathrm{~W}$ drodze do Torunia wielkiemu mistrzowi towarzyszyli członkowie Zakonu (Georg Truchsess, Heinrich von Miltitz, Michael von Drahe), przedstawiciele szlachty (Heinrich von Kittlitz, Kunz Truchsess, Dietrich von Schlieben) oraz przedstawiciele Królewca (Asmus Becher i Martin Röseler). Cały orszak był eskortowany przez polskie oddziały - por. J. Wijaczka, Albrecht von Brandenburg-Ansbach, s. 66.

${ }^{62}$ ASPK, t. 8, nr 6

${ }^{63}$ ASPK, t. 8, nr 8, s. 32; Die Danziger Chronik vom Bunde warscheinlich v. Peter Brambeck, hrsg. v. T. Hirsch, [w:] Scriptores Rerum Prussicarum. Die Geschichtsquellen der preussischen Vorzeit bis zum Untergange der Ordensherrschaft, hrsg. v. T. Hirsch, M. Töppen und E. Strehlke, Bd. 4, Leipzig 1870, s. 508.

${ }^{64}$ J. Wijaczka, Albrecht von Brandenburg-Ansbach, s. 66. 
skimi nad przedłużeniem glejtu dla wielkiego mistrza, a także rozejmu. Zaproponowano, aby przedłużyć je o osiem dni ${ }^{65}$. Prosili o to posłowie krzyżaccy, którzy tego samego dnia zostali przyjęci przez króla. Monarcha zgadzał się na nie o tyle, o ile Hohenzollern uzna formułę rozmów na podstawie poprawionych artykułów traktatu toruńskiego z $1466 \mathrm{r}$., które były mu dosłane jeszcze do Królewca, Zygmunt nie zamierzał bowiem odstąpić od warunków tegoż traktatu ${ }^{66}$. Dnia 20 czerwca w toruńskim ratuszu przyjął na audiencji zwierzchnika Zakonu. W negocjacjach uczestniczyli również radcy koronni i pruscy ${ }^{67}$. Po debatach ze stanami pruskimi i radcami królewskimi król zadecydował ostatecznie, że i glejt, i rozejm zostaną przedłużone o osiem dni, do 1 lipca $1520 \mathrm{r}^{68}$ Po podjęciu tej decyzji Zygmunt Stary wysłał kanclerza koronnego Krzysztofa Szydłowieckiego oraz podkanclerzego Piotra Tomickiego do gospody na Starym Mieście, w której zamieszkał Albrecht, aby przekazali mu tę wiadomość ${ }^{69}$. Następnie postanowiono wstrzymać rozmowy do czasu przyjazdu do miasta biskupa pomezańskiego Hioba Dobenecka. Pod koniec dnia król rozmawiał jeszcze z posłami gdańskimi, którzy poprosili Zygmunta I o instrukcje, jak mają zachowywać się w tym okresie gdańskie okręty. Król nakazał czuwanie i gotowość ${ }^{70}$. Przedstawiciele Gdańska przekazali mu ponadto wieści od Rady swojego miasta, dotyczące dosyłania morzem dalszych zbrojnych do Prus Zakonnych ${ }^{71}$.

Dnia 21 czerwca wznowiono obrady. Wielki mistrz podsunął pomysł, aby podjąć rozmowy poprzez komisję złożoną z trzech osób ze strony krzyżackiej i trzech ze strony polskiej. Pomysłu tego nie przekazał Zygmuntowi I osobiście, lecz za pośrednictwem swoich po-

\footnotetext{
${ }^{65}$ ASPK, t. 8, nr 8, s. 33.

${ }^{66}$ Ibid., s. 34.

${ }^{67} \mathrm{~W}$ czasie jej trwania Albrecht prosił, tak jak wcześniej jego posłowie, o przedłużenie glejtu i rozejmu. Monarcha jednak ponownie odroczył podjęcie decyzji w tej sprawie do czasu kolejnej narady ze stanami pruskimi i dostojnikami królewskimi ibid., s. 35 .

${ }^{68}$ Ibid., s. 35-36.

${ }^{69}$ J. Wijaczka, Albrecht von Brandenburg-Ansbach, s. 66.

${ }^{70}$ ASPK, t. 8, nr 8, s. 38.

${ }^{71}$ ASPK, t. 8, nr 7 .
} 
słów $^{72}$. Polski monarcha zaaprobował go, jednak wprowadził jedną zmianę - zwiększył liczbę przedstawicieli obu stron w komisji z trzech do sześciu. Strona polska była reprezentowana między innymi przez biskupa Fabiana Luzjańskiego i wojewodę malborskiego Jerzego Bażyńskiego $^{73}$. Po zakończeniu obrad członkowie komisji przekazali królowi sprawozdanie $\mathrm{z}$ ich przebiegu. Monarcha po zapoznaniu się $\mathrm{z}$ relacją nadal obstawał przy złożeniu mu przez Albrechta niezmienionej przysięgi wierności ${ }^{74}$. Wieść o nieugiętej postawie króla nie zadowoliła wielkiego mistrza, który wznowił opór. Spowodowało to zakończenie działań komisji. Odtąd prowadzono już tylko poufne rozmowy przedstawicieli władcy i Zakonu. Relacje z nich przekazywał Zygmuntowi podkanclerzy koronny Piotr Tomicki. Reprezentanci Królestwa nadal uważali postanowienia II traktatu toruńskiego za jedyną gwarancję pokoju. Ponieważ Hohenzollern także trwał w uporze i nie dawał się przekonać argumentom polskiej strony, biskup Dobeneck zaproponował przedłużenie glejtu i rozejmu o kolejne 5 dni, aby wielki mistrz mógł porozumieć się w kwestii przysięgi z władzami Zakonu i stanami Prus Krzyżackich, które były za ustępstwami na rzecz Zygmunta I. Biskup miał więc nadzieję, iż przekonają Albrechta do zaprzestania oporu i spełnienia przez niego swojej powinności ${ }^{75}$. Później jednak wielki mistrz poprosił o poufne spotkanie z królem w wąskim gronie, na co ten przystał. Odbyło się ono 22 czerwca, prawdopodob-

\footnotetext{
${ }^{72}$ ASPK, t. 8, nr 8, s. 37.

${ }^{73}$ Komisja rozpoczęła obrady 21 czerwca w Ratuszu Staromiejskim. Najpierw strona krzyżacka skarżyła się na bezprawne zabranie Zakonowi przez Polskę ziem chełmińskiej, michałowskiej oraz Pomorza Gdańskiego. Później podkreślała fakt, iż ani papiestwo, ani cesarstwo nie zaakceptowało traktatu toruńskiego. $\mathrm{Na}$ koniec posłowie krzyżaccy dodali, że honor i dobro zakonu krzyżackiego nie pozwalają wielkiemu mistrzowi złożyć polskiemu królowi przysięgi wierności. Mogą to natomias uczynić jego poddani. Z kolei strona polska w ogóle odrzucała dyskusje na temat traktatu z 1466 r. Powoływano się przy tym na fakt zaprzysiężenia go przez poprzedników obecnego zwierzchnika Zakonu. Uznano również, że niezatwierdzenie go przez papiestwo i cesarstwo nie zwalniają wielkiego mistrza od składania przysięgi wierności polskiemu władcy. Dopuszczono jedynie możliwość niewielkiego złagodzenia warunków pokoju toruńskiego - ibid., s. 38-41.

${ }^{74}$ Ibid., s. 41.

75 Ibid., s. 42-43.
} 
nie, jak zawsze, w Ratuszu Staromiejskim. W czasie dyskusji Albrecht wyliczył punkty traktatu, które są sprzeczne z interesem Zakonu. Prosił o przedłużenie glejtu i rozejmu o kolejne 5 dni. Na koniec swojej przemowy stwierdził, iż chciałby koniecznie porozumieć się ze stanami Prus Krzyżackich i w związku z tym poprosił polskiego monarchę o zgodę na podróż do Królewca ${ }^{76}$. Dla króla i jego przedstawicieli argumenty przedstawione przez zwierzchnika Zakonu były niewystarczające i nadal wskazywali oni na brak podstaw do sprzeciwu Albrechta wobec postanowień traktatu. Dodatkowo król wypomniał wielkiemu mistrzowi zawarcie przymierza z Moskwą oraz sprowokowanie obecnie trwającej wojny ${ }^{77}$. Albrecht odrzucał zarzuty i nadal trwał w uporze, podobnie jak polski król. Z powodu zaistniałego impasu Zygmunt Stary 23 czerwca odbył kolejne obrady ze swoimi doradcami. Postanowiono na nich, że albo wielki mistrz w końcu ustąpi i złoży przysięgę wierności, albo zostanie zmuszony do natychmiastowego opuszczenia Torunia. Hohenzollern nie odpowiedział od razu, tylko prosił o czas na udanie się do Królewca i porozumienie się w tej sprawie z dostojnikami Zakonu i stanami Prus Krzyżackich ${ }^{78}$. Dnia 24 czerwca na prośbę biskupa Dobenecka odbyło się, za zgodą polskiego króla, poufne spotkanie biskupa $\mathrm{z}$ arcybiskupem Łaskim w sprawie przysięgi i ewentualnej zgody na konsultacje Albrechta ze swoimi doradcami ${ }^{79}$. Dzień później (25 czerwca) Zygmunt Stary po raz kolejny przyjął na audiencji posłów krzyżackich. Ci, próbując dalej szukać tłumaczeń dla oporu swojego władcy, twierdzili, że nie są mu znane korzyści dla Zakonu po złożeniu hołdu. Polski król zapewnił, że będą one znaczne. Podczas rozmów posłowie krzyżaccy domagali się jeszcze restytucji strat wy-

\footnotetext{
${ }^{76}$ J. Wijaczka, Albrecht von Brandenburg-Ansbach, s. 66.

${ }^{77}$ ASPK, t. 8, nr 8, s. 43-45.

${ }^{78}$ Ibid., s. 45-47.

${ }^{79}$ Rozważano również możliwość przeniesienia zakonu krzyżackiego na dalsze terytoria, gdzie Krzyżacy otrzymaliby więcej ziemi i ludzi, i gdzie faktycznie mogliby walczyć z wrogami chrześcijaństwa. Biskup Dobeneck i arcybiskup Łaski optowali za zgodą na wyjazd do Królewca. Król jednak wyraził nieufność wobec zamiarów krzyżackiego władcy. Zgodził się na jego podróż do stolicy Zakonu pod warunkiem, że zapewni o ostatecznym złożeniu przysięgi wierności. Ten jednak nie przystawał na to i chciał wyjechać bez żadnych warunków - ibid., nr 8, s. 48-50.
} 
rządzonych w czasie trwającej polsko-krzyżackiej wojny. Na koniec postulowali przedłużenie rozejmu o kilka $\mathrm{dni}^{80}$. Dzień później, 26 czerwca, na prośbę wielkiego mistrza odbyło się w ratuszu kolejne jego spotkanie z Zygmuntem. Król przyjął go w otoczeniu swoich radców. Podczas negocjacji wielki mistrz powtórzył swoje żądania z 22 czerwca $^{81}$. Dodatkowo domagał się wyjaśnienia sprawy zamków i miast okupowanych przez Królestwo Polskie w czasie trwającej „wojny pruskiej”82. Król postanowił naradzić się wraz ze swoimi doradcami, jak rozwiązać kwestię zwrotu Krzyżakom niektórych zamków i miast znajdujących się w Dolnych Prusach ${ }^{83}$. Co do wydania zgody na wyjazd wielkiego mistrza do Królewca król stwierdził, że Albrecht może jedynie wysłać tam swoich radców, ale najpierw musi on książęcym słowem zaręczyć, że po ich powrocie złoży przysięgę na traktat toruński z $1466 \mathrm{r}^{84} \mathrm{~W}$ kwestii treści II pokoju król zapowiedział jedynie, że zostaną ułożone specjalne dodatkowe artykuły, które będą miały na celu jego wzmocnienie. Ich projekt powstał już następnego dnia i został przedstawiony przez Tomickiego Zygmuntowi oraz radcom królewskim i pruskim. Swój projekt zmiany niektórych punktów, oczywiście $\mathrm{z}$ uwzględnieniem dobra Zakonu, wysunęli także posłowie papiescy. Następnie oba pomysły zostały przekazane przez podkanclerzego do konsultacji Albrechtowi Hohenzollernowi ${ }^{85}$. Ten jednak nadal nalegał na wydanie przez Zygmunta zgody na jego podróż do Królew$\mathrm{ca}^{86}$. Dnia 27 czerwca w Ratuszu Staromiejskim odbyło się kolejne spotkanie króla z radcami ${ }^{87}$. Po odrzuceniu przez Albrechta przedsta-

\footnotetext{
${ }^{80}$ Ibid., s. 50-53.

${ }^{81}$ J. Wijaczka, Albrecht von Brandenburg-Ansbach, s. 67.

${ }^{82}$ ASPK, t. 8, nr 8, s. 53-54.

${ }^{83}$ Jedną z wysuniętych propozycji było oddanie w zamian Braniewa wraz z artylerią. Ostatecznie jednak zadecydowano, że restytucją strat zajmie się powołana później komisja rozjemcza - ibid., s. 54-55.

${ }^{84}$ Wielki mistrz takową przysięgę złożył - J. Wijaczka, Albrecht von Brandenburg-Ansbach, s. 67.

${ }^{85}$ ASPK, t. 8, nr 8, s. 56-58

${ }^{86}$ Ibid., s. 59-60.

${ }^{87} \mathrm{~W}$ czasie jego trwania podkanclerzy Tomicki przedstawił wykaz 23 punktów do traktatu z 1466 r., które miały umocnić jego postanowienia oraz wprowadzić dodatkowe gwarancje realizacji i stabilizacji owego dokumentu, nieznacznie tylko łagodząc
} 
wionych mu propozycji rozgoryczony postawą swojego siostrzeńca polski monarcha w końcu wyraził zgodę na wyjazd zwierzchnika Zakonu, ale stwierdził również, że swoją postawą doprowadził on do zerwania rokowań pokojowych ${ }^{88}$. Zygmunt Stary nie zgodził się na to, aby wielki mistrz pożegnał się z nim przed wyjazdem z Torunia. Ten już więcej nie nalegał. Dnia 28 czerwca opuścił miasto pod eskortą wojsk królewskich z glejtem ważnym do 4 lipca $1520 \mathrm{r}^{89}$

Po wyjeździe wielkiego mistrza z Torunia polski król zajął się kwestią podatków na cele wojenne oraz wewnętrznymi sprawami i konfliktami miast pruskich. Zygmunt Stary wezwał radców pruskich, przedstawicieli szlachty oraz małych miast Prus Królewskich do jak najszybszego uchwalenia podatków na pokrycie kosztów wojny ${ }^{90}$. Z powodu ponagleń władcy stany pruskie dnia 29 czerwca odbyły naradę, na której rozważano propozycje nałożenia nowych opłat ${ }^{91}$. W sprawie ich poboru naradzały się one między innymi $\mathrm{z}$ arcybiskupem Łaskim i biskupem włocławskim Maciejem Drzewickim ${ }^{92}$. Radcy pruscy poinformowali Zygmunta Starego o zaistniałym oporze przedstawicieli wielkich miast pruskich. Poprosili władcę, aby ten interweniował i sprawił, by przyłączyły się one do uchwały podatkowej. Król tak też uczynił i nakazał

warunki dla wielkiego mistrza. Ten po zapoznaniu się z nimi nie chciał ich zaakceptować bez konsultacji ze stanami Prus Krzyżackich. Ponadto w tym czasie do Albrechta dotarła wiadomość, iż do Królewca dotarli zaciężni z Danii. Dzięki ich wsparciu Zakon miałby wreszcie możliwość podjęcia akcji ofensywnej przeciwko Królestwu. $\mathrm{Z}$ tego powodu wielki mistrz postanowił odrzucić wszelkie propozycje strony polskiej. $\mathrm{Na}$ dodatek złożył skargę na polskich zaciężnych, którzy pomimo trwania rozejmu wyrządzali szkody jego poddanym w Prusach Dolnych i na Mierzei Wiślanej. Na koniec siostrzeniec Zygmunta poprosił go o glejt na drogę powrotną - J. Wijaczka, Albrecht von Brandenburg-Ansbach, s. 67.

${ }^{88}$ ASPK, t. 8, nr 8, s. 60-61.

${ }^{89}$ Ibid., nr 8, s. 62; J. Wijaczka, Albrecht von Brandenburg-Ansbach, s. 67-68.

${ }^{90}$ ASPK, t. 8, nr 8, s. 58.

${ }^{91}$ Ibid., s. 62-63.

${ }^{92}$ Podczas rozmów ustalono między innymi tekst uchwały podatkowej dotyczącej ludności wiejskiej Prus Królewskich, która miała zacząć obowiązywać od 25 lipca 1520 r. Uczestniczący w obradach przedstawiciele wielkich miast pruskich byli przeciwko zapowiadanemu obciążeniu i aby jak najbardziej wydłużyć okres do jego nałożenia odroczyli udzielenie odpowiedzi w kwestii nowego podatku do czasu skonsultowania się ze swoimi mocodawcami - ibid., s. 64-66. 
poselstwom wielkich miast pruskich do dnia 25 lipca udzielenie odpowiedzi w tej kwestii ze strony ich władz samorządowych ${ }^{93}$.

Dnia 5 lipca monarcha zaniepokojony sytuacją na północy kraju polecił posłom gdańskim obecnym w Toruniu, aby przekazali władzom swojego miasta, by ich okręty były bardziej czujne na morzu i nie dopuszczały do przybywania dalszych zaciężnych z Danii, udających się z pomocą Krzyżakom. Nakazał również gdańszczanom, aby czuwali także na Zalewie Wiślanym. Prosił też o to, aby Gdańsk dostarczał żywność działającym na tych terenach wojskom Królestwa Polskiego. Z kolei posłowie prosili króla, aby część dochodu z nowo nałożonego podatku mogła zostać przeznaczona na pokrycie kosztów ekspedycji ich okrętów. Król jednak odroczył wydanie decyzji w tej kwestii $^{94}$.

Z wewnętrznych spraw Prus Królewskich monarchę absorbował między innymi zatarg szlachcica, niejakiego Macieja Sławutowskiego, $\mathrm{z}$ miastem Gdańskiem ${ }^{95}$. Zygmunt Stary polecił wydać orzeczenie w tej sprawie do 25 lipca 1520 r. Natomiast gdańszczanom bezwzględnie zakazał napadania na szlachtę w jej domach. Potem władca rozpatrywał kolejne roszczenia wyżej wspomnianego szlachcica, tym razem do wsi Żelistrzewo. Jednak w tym przypadku król odrzucił wszelkie jego roszczenia ${ }^{96}$.

Następnie znowu powrócono do konfliktu $\mathrm{z}$ wielkim mistrzem. Dnia 10 lipca do Torunia dotarł list od Albrechta, w którym zawiadamiał on polskiego władcę o nowym składzie jego poselstwa zmierzającego na spotkanie $\mathrm{z}$ królem. To zapowiedziane listownie przedstawicielstwo krzyżackie wraz z biskupem pomezańskim Dobeneckiem 12 lipca dotarło do Torunia. Monarcha do rozmów z nim wydelegował kilku swoich reprezentantów na czele $\mathrm{z}$ arcybiskupem Łaskim ${ }^{97}$. Sprawozdanie z rozmów przedstawiono później Zygmuntowi Staremu oraz

\footnotetext{
${ }^{93}$ Ibid., s. 65-67.

${ }^{94}$ Ibid., s. 67-68.

95 Ibid., s. 62-63.

${ }^{96}$ Ibid., s. 67.

${ }^{97}$ Ibid., s. 69-70.
} 
radcom królewskim i pruskim ${ }^{98}$. Monarcha po zapoznaniu się z relacją odrzucił wszelkie propozycje i roszczenia wielkiego mistrza. W uzasadnieniu tej decyzji stwierdził, iż sformułowane pomysły zmierzają do przywrócenia w Prusach stanu sprzed 200 lat. Zapowiedział również, że ani on, ani Korona Polska nie zamierzają odstąpić od postanowień traktatu toruńskiego. Na koniec monarcha oświadczył, że wszelkie dyskusje z posłami zakonu krzyżackiego są bezcelowe i nie chciał przyjąć ich na audiencji ${ }^{99}$.

Jednak później, po namowach radców królewskich, zmienił zdanie i zdecydował się przeprowadzić z nimi rozmowy ${ }^{100}$. Zostali oni przyjęci w ratuszu przez króla 14 lipca. Na początku posłowie powtórzyli żądania i postulaty wielkiego mistrza. Pomysły te ponownie stanowczo odrzucono. Uczynił to podkanclerzy Tomicki, który stwierdził, że tego typu propozycje ze strony Krzyżaków zmierzają do zlikwidowania traktatu toruńskiego, do czego zarówno Zygmunt Stary, jak i całe Królestwo Polskie nie zamierzają dopuścić. Następnie na wezwanie polskiego króla biskup pomezański przedstawił główne powody niepokoju wielkiego mistrza dotyczące niektórych artykułów ${ }^{101}$. Przysłuchujący się tym rozmowom krzyżacki prokurator z Nidzicy Henryk von Miltitz poprosił o możliwość osobnej narady posłów zakonnych. Taka się odbyła i po niej krzyżaccy wysłannicy ponownie zostali przyjęci przez króla na audiencji, podczas której powtórzyli zastrzeżenia swojego zwierzchnika. Na zakończenie biskup Dobeneck poprosił Zygmunta

\footnotetext{
${ }^{98}$ Rozpoczęły się one 13 lipca od przedłożenia przez posłów wielkiego mistrza przedstawicielom Zygmunta I zastrzeżeń dotyczących 23 artykułów złożonych Albrechtowi Hohenzollernowi podczas jego pobytu w Toruniu. Strona krzyżacka przedstawiła w imieniu swojego zwierzchnika propozycję przekazania zakonowi krzyżackiemu przez Królestwo Polskie Pomorza Gdańskiego na warunkach lenna. Następnie wypowiedziała się strona polska, która uznała, że Krzyżacy takimi działaniami zmierzają do dalszego prowadzenia wojny. Biskup Dobeneck uczestniczący w rozmowach próbował usprawiedliwiać postawę Albrechta, tłumacząc ją zniszczeniami Prus Zakonnych, jednak na próżno - ibid., s. 70-74.

${ }^{99}$ Ibid., s. 74-75.

${ }^{100}$ Ibid., s. 78 .

${ }^{101}$ Chodziło między innymi o sprawy oddania Braniewa wraz z uzbrojeniem czy też dalszego okupowania przez Polskę pruskich miast i zamków do końca wojny ibid., s. 77-78.
} 
o łaskę i o życzliwość dla Zakonu. Jednak zirytowany król stwierdził, że dalsze rokowania na podstawie artykułów wielkiego mistrza są bezcelowe i nie chciał kontynuować obrad ${ }^{102}$.

Dnia 15 lipca odbyła się rozmowa kanclerza koronnego Krzysztofa Szydłowieckiego i podkanclerzego Tomickiego z biskupem Dobeneckiem $^{103}$. Relacja $\mathrm{z}$ niej została następnie przekazana królowi. Zygmunt Stary po naradzie ze swoimi doradcami odrzucił jednak propozycje biskupa pomezańskiego. Zgodził się jedynie na pozostawienie pruskich miast i zamków pod obecną władzą aż do czasu oszacowania wydatków poniesionych na wojnę i potwierdzenia traktatu toruńskiego z 1466 r. przez papiestwo. Na tym zakończono rokowania z poselstwem wielkiego mistrza. Następnego dnia, 16 lipca, biskup oraz krzyżaccy posłowie wyjechali z Torunia i wyruszyli do Królewca ${ }^{104}$.

\section{Kontynuacja wojny. Rokowania pokojowe - część druga (lato 1520 - 25 IV 1521 r.)}

Po zakończeniu rokowań pokojowych w lipcu 1520 r. wznowiono walkę zbrojną. Kampania letnia okazała się jednak niepomyślna dla Polski ${ }^{105}$. Dodatkowo królowi kończyły się środki na kontynuowanie działań wojennych. $\mathrm{Z}$ tego powodu zapożyczał się u różnych osób. Przykładowo w dokumencie wystawionym w sierpniu 1520 r. znalazła się informacja, że polski władca na opłacenie zaciężnych pożyczył od biskupa poznańskiego Piotra Tomickiego 1000 florenów węgierskich i zobowiązał się, że spłaci dług do 11 listopada 1521 r. $^{106}$

\footnotetext{
102 Ibid., s. 77-79.

${ }^{103} \mathrm{~W}$ jej trakcie biskup ponownie przedstawił sprawę Braniewa oraz okupowania pruskich zamków i miast przez wojska polskie. Zaproponował, aby Polacy przekazali je pod zarząd strony neutralnej, co mogłoby wpłynąć pozytywnie na postawę wielkiego mistrza i spowodować zmianę jego decyzji w kwestii dalszego oporu - ibid., s. 80 .

${ }^{104}$ Ibid., s. 81

${ }^{105}$ Między innymi z powodu nieudanego oblężenia Braniewa przez wojska polskie czy zdobycia przez zakon krzyżacki Pisza. Atakowana przez Krzyżaków była również Warmia, a ściślej - Lidzbark Warmiński, który jednak stawiał skuteczny opór - J. Wijaczka, Albrecht von Brandenburg-Ansbach, s. 68.

${ }^{106}$ Matricularum, pars 4, nr 3449.
} 
Były też jednak dobre wieści. Otóż w sierpniu do Torunia dotarła do króla wiadomość przekazana przez wojewodę kaliskiego Jana Zarembę o tym, iż królowa Bona urodziła mu syna - Zygmunta Augusta. $\mathrm{Z}$ tej okazji we wszystkich toruńskich kościołach odprawiano msze dziękczynne. W niektórych król uczestniczył osobiście. Podczas nich śpiewano zwyczajowo, jak za każdym razem przy tego rodzaju specjalnych okazjach, „Te Deum Laudamus”. Rada Miasta Torunia zarządziła wówczas ,wieczór radości”. Zorganizowano zabawy i publiczne bankiety. Dodatkowo na polecenie polskiego władcy przed Dwór Artusa wytoczono dla ludu piwo gdańskie i odpalono sztuczne ognie ${ }^{107}$.

Dnia 30 września monarcha opuścił miasto, aby wraz z pospolitym ruszeniem bronić Poznania zagrożonego przez krzyżacką armię. Przed wyjazdem król wynagrodził Toruń, wystawiając przywilej zwalniający miejscowych kupców na okres 10 lat od opłat celnych od ryb wywożonych na Śląsk. Podarował także miastu kilka okolicznych wsi ${ }^{108}$. Kampania jesienna przechyliła szalę zwycięstwa na korzyść Polski. Powiodła się między innymi obrona Lidzbarka Warmińskiego dzięki armii dowodzonej przez hetmana Jakuba Sęcygniewskiego w Prusach Krzyżackich ${ }^{109}$. Nie poddała się również załoga zamku w Olsztynie dzięki odpowiednim przygotowaniom administratora kapitulnego Mikołaja Kopernika ${ }^{110}$. Jednak wypracowanej jesienią przewagi Królestwo Polskie nie wykorzystało. Spowodowane to było brakiem wyraźnej strategii, a także wystarczających środków finansowych.

W grudniu, ze względu na nadejście zimy, przerwano działania wojenne ${ }^{111}$. Pod koniec roku król dotarł do Torunia przejazdem w drodze do Brześcia Kujawskiego. W tym czasie wystawił w mieście kilka

\footnotetext{
107 Thorner Denkwürdigkeiten, s. 150; M. Murinius, Kronika Abo opisanie ziemie i Mistrzów Pruskich, na polskie z niemieckiego przełożona, z przydaniem rzeczy pamięci godnych z rozmaitych kronik zebranych. Przez Marcina Muriniusa niekiedy wydana: a teraz po wtóre na wielu miejscach poprawiona i do druku podana, Kraków 1606, s. 157; J. Małłek, Ostatni Jagiellonowie, s. 27.

${ }_{108}$ M. Biskup, U schyłku średniowiecza, s. 184.

${ }^{109}$ J. Wijaczka, Albrecht von Brandenburg-Ansbach, s. 68.

${ }^{110}$ G. Labuda, M Biskup, Dzieje zakonu krzyżackiego w Prusach: gospodarka, spoteczeństwo, państwo, ideologia, Gdańsk 1988, wyd. 2, s. 473-474.

${ }^{111}$ J. Wijaczka, Albrecht von Brandenburg-Ansbach, s. 68.
} 
dokumentów. Dla przykładu 26 grudnia 1520 r., nawiązując do wcześniejszego zapisu króla Aleksandra Jagiellończyka, Zygmunt Stary postanowił, aby wdowa po burmistrzu toruńskim Henryku Krügerze, Krystyna, mogła posiadać wieś Rogówko aż do spłacenia przez króla należnej jej sumy 200 guldenów $^{112}$.

Początek ostatniej fazy wojny rozpoczął się w styczniu $1521 \mathrm{r}$. Jednocześnie $\mathrm{w}$ Toruniu przygotowywano się do prowadzenia rokowań pokojowych, w których mieli uczestniczyć pośrednicy międzynarodowi, wśród nich między innymi posłowie cesarza Karola V oraz króla Czech i Węgier Ludwika Jagiellończyka. Początek rozmów zaplanowano na 25 stycznia $^{113}$. W liście wysłanym 5 stycznia 1521 r. przebywający w Brześciu Kujawskim Zygmunt I informował Radę Miasta Gdańska, iż poselstwo Karola V i Ludwika Jagiellończyka zapowiedziało swój przyjazd do Torunia na 25 stycznia 1521 r. w celu podjęcia prób doprowadzenia do pokoju pomiędzy Polską a zakonem krzyżackim. W związku z tym król nakazał Radzie przysłać do Torunia swoich przedstawicieli ${ }^{114}$. Z kolei 21 stycznia, również z Brześcia, polski władca przesłał list do Rady Miasta Torunia, w którym zawiadamiał, że 23 stycznia wyruszy w drogę do Torunia i przybędzie dzień później. W związku z tym nakazał przygotować pomieszczenia w Ratuszu Staromiejskim, w których miał zamieszkać w czasie prowadzenia rokowań pokojowych ${ }^{115}$.

Posłowie cesarscy oraz reprezentujący Ludwika Jagiellończyka książę legnicki Fryderyk II dotarli do Torunia 26 stycznia ${ }^{116}$. Obrady rozpoczęły się 28 stycznia. Tego dnia Zygmunt I w otoczeniu radców z Korony i Prus przyjął posłów na audiencji w Ratuszu Staromiejskim. W imieniu wszystkich przybyłych dyplomatów przemawiał wysłannik cesarski Sebastian Sperantius, który wzywał Zygmunta Starego przede wszystkim do zawieszenia broni z wielkim mistrzem Albrechtem i podjęcia z nim rokowań pokojowych. Chciano zaprzestania przelewu krwi

\footnotetext{
${ }^{112}$ Katalog dokumentów, nr 229.

${ }^{113}$ Cesarza reprezentowali hrabia Georg von Roggendorf i prepozyt brikseński Sebastian Sprentz - J. Wijaczka, Albrecht von Brandenburg-Ansbach, s. 75.

${ }^{114}$ ASPK, t. 8, nr 14.

115 Ibid., nr 15.

${ }^{116}$ J. Wijaczka, Albrecht von Brandenburg-Ansbach, s. 75.
} 
chrześcijańskiej i podjęcia walki z wrogami chrześcijaństwa ${ }^{117}$. Dzień później posłowie poinformowali władcę, iż zamierzają wysłać listy do Albrechta Hohenzollerna, aby ten zaprzestał działań wojennych. Zygmunt poinformował o tym swoich doradców. Po naradach z nimi król postanowił odrzucić ten projekt, dopóki posłowie nie ujawnią mu swoich propozycji rozjemczych. W tej sytuacji 31 stycznia poselstwo cesarza i króla czesko-węgierskiego wysunęło inny pomysł, a mianowicie przekazania polsko-krzyżackiego sporu pod sąd rozjemczy Karola V i Ludwika Jagiellończyka. Król postanowił naradzić się nad tą propozycją z radcami koronnymi i pruskimi ${ }^{118}$.

Ponieważ kolejna audiencja $\mathrm{z}$ udziałem posłów cesarza i króla węgierskiego odbyła się dopiero 12 lutego, Zygmunt I w czasie swojego pobytu w Toruniu zajmował się innymi sprawami. Dnia 1 lutego w obecności króla odczytano list elektora brandenburskiego Joachima, który chciał oczyścić się z zarzutów o wrogą postawę wobec Królestwa Polskiego i sprzyjanie Zakonowi ${ }^{119}$. Innego dnia król przyjął poselstwo tatarskie, które zaoferowało Polsce pomoc ze strony chana krymskiego Mohammeda Gireja w wypadku dalszej wojny z zakonem krzyżackim, a także w razie ataku Moskwy ${ }^{120}$.

W następnych dniach ( 7 i 8 lutego) król spotkał się z przedstawicielami wyższego kleru koronnego, którzy przybyli po zakończeniu synodu piotrkowskiego. Rozmawiali oni z monarchą na temat uchwał podatkowych sejmu bydgoskiego z $1520 \mathrm{r}^{121} \mathrm{~W}$ drugim dniu rozmów Zygmunt Stary wyjaśniał reprezentantom duchowieństwa kwestię podatkowych uchwał bydgoskich i zapewnił ich, że przywileje Kościoła

${ }^{117}$ ASPK, t. 8, nr 18, s. 102.

118 Ibid., s. 104.

${ }^{119} \mathrm{~W}$ tej sprawie w późniejszym okresie, 13 kwietnia 1521 r., Zygmunt Stary otrzymał list od cesarza Karola V, który bronił postawy elektora wobec Polski. Polacy mieli jednak inne zdanie, cesarz więc zaproponował sądowe rozstrzygnięcie tego zatargu ibid., s. 127.

${ }^{120}$ Ibid., s. 105 .

${ }^{121} \mathrm{~W}$ ich rozumieniu zostały one przyjęte bez udziału prałatów i wbrew przywilejom stanu duchownego, dlatego władca powinien złożyć zapewnienie o nienaruszalności uprawnień Kościoła. Poinformowali również monarchę, iż zamierzają wysłać skargę do papieża Leona $\mathrm{X}$ na zabór dóbr biskupstwa warmińskiego oraz niszczenie dóbr biskupstwa chełmińskiego przez zakon krzyżacki - ibid., s. 106. 
pozostaną nienaruszone. Co do zamiaru złożenia przez nich skargi do papieża, zaakceptował ten pomysł ${ }^{122}$.

Dnia 10 lutego do Torunia przybyli kolejni posłowie Ludwika Jagiellończyka - margrabia brandenburski Jerzy i Ambroży Sarkan. Wreszcie 12 lutego król przyjął na audiencji w ratuszu delegatów cesarza i króla węgierskiego. Przedstawiciele Ludwika Jagiellończyka wygłosili mowę, w której wyjaśniali, iż po niepowodzeniu misji pokojowej posłów książąt Rzeszy w Prusach ich władca, ze względu na pokrewieństwo z Zygmuntem i przelew chrześcijańskiej krwi, zdecydował się ich tutaj przysłać. Cesarz Karol V uczynił to samo. Dyplomaci węgierscy wzywali polskiego władcę do podjęcia rokowań pokojowych $z$ Zakonem i zawieszenia broni ${ }^{123}$. Zygmunt jednak na przedstawione warunki rozejmu się nie zgadzał. Dzień później w towarzystwie radców koronnych i pruskich monarcha kontynuował rozmowy z wysłannikami - sekretarz królewski, Andrzej Krzycki, przedstawił polski punkt widzenia w konflikcie z Zakonem. Dnia 14 lutego król dyskutował z posłami już bez udziału radców, ale wciąż rozmowy nie odnosiły żadnego skutku ${ }^{124}$. Później posłowie cesarscy i węgierscy udali się do Prabut, gdzie miało się odbyć zaplanowane przez nich spotkanie $\mathrm{z}$ wielkim mistrzem ${ }^{125}$.

Dnia 20 marca król wraz ze swoimi doradcami przyjął kolejne poselstwo. Tym razem był to nuncjusz papieski Zachariasz Ferreri. Przybył on do Zygmunta $\mathrm{z}$ wiadomością, iż wielki mistrz jest gotowy zawrzeć z nim pokój. Następnie posłowie, którzy wrócili z Prabut, zdali królowi relacje $\mathrm{z}$ rozmów $\mathrm{z}$ najwyższym zwierzchnikiem Zakonu. Zgodził się on jedynie na rozejm i sąd rozjemczy Karola V i Ludwika Jagiellończyka.

${ }^{122}$ Ibid., s. 106-107.

${ }^{123}$ Zwłaszcza że cesarz Karol V zwołał zjazd do Pasawy, gdzie chciał się spotkać z Ludwikiem Jagiellończykiem i Ferdynandem Habsburgiem. Wzywał tam także Zygmunta, na co bardzo nalegał zwłaszcza król węgierski - ibid., s. 108.

${ }^{124}$ Ibid., s. 108-109.

${ }^{125}$ Udali się tam 2 marca. Natomiast zwierzchnik Zakonu dotarł na miejsce wraz ze swoją świtą 8 marca. Dnia 19 marca część z obecnych, po bezowocnych rozmowach, wróciła do Torunia - ibid., s. 110-111; J. Wijaczka, Albrecht von BrandenburgAnsbach, s. 75-76. 
W następnych dniach w Ratuszu Staromiejskim debatowano nad warunkami przerwania działań wojennych oraz nad sądem polubownym cesarza. Podczas rozmów posłowie cesarscy skupiali się głównie na sprawie zawieszenia broni, natomiast radcy królewscy akcentowali nienaruszalność traktatu toruńskiego z $1466 \mathrm{r}$. Król na prośbę delegatów zgodził się na udostępnienie im dokumentów II pokoju toruńskiego oraz deklaracji cesarza Maksymiliana I z 1515 r. z Wiednia potwierdzającej nienaruszalność traktatu. Dnia 23 marca posłowie zaproponowali 4-letni rozejm liczony od 7 kwietnia 1521 r. ${ }^{126}$ Dzień później przebywający w Toruniu dostojnicy wzięli udział w ceremoniach kościelnych $\mathrm{z}$ okazji przypadającej tego dnia Niedzieli Palmowej. Po ich zakończeniu, po południu, rozmowy zostały wznowione ${ }^{127}$.

Dnia 30 marca do Torunia przyjechali z Prabut pozostali cesarscy i węgierscy posłowie $\mathrm{w}$ towarzystwie kilku delegatów wielkiego mistrza i stanów Prus Krzyżackich. Zdali oni królowi relację z rokowań z najwyższym zwierzchnikiem Zakonu ${ }^{128}$. Poinformowali między in-

\footnotetext{
${ }^{126}$ ASPK, t. 8, nr 18, s. 112-114; J. Wijaczka, Albrecht von Brandenburg-Ansbach, s. 76.

${ }^{127}$ ASPK, t. 8, nr 18, s. 112.

${ }^{128}$ Przybyli do Prabut posłowie przedłożyli wielkiemu mistrzowi propozycję złożenia królowi przysięgi na podstawie traktatu toruńskiego z 1466 r., co zapewniłoby Albrechtowi królewską łaskawość. Zwierzchnik Zakonu odrzucił ten postulat, ponieważ stwierdził, iż jego poprzednicy byli zmuszani siłą do jej składania, ze szkodą dla Zakonu. Uważał również, że traktat ten stanowi poważny uszczerbek dla autorytetu cesarza i Świętego Cesarstwa Rzymskiego oraz papiestwa, któremu zakon krzyżacki bezpośrednio podlega, a które to instytucje zakazywały wcześniej składania tej przysięgi. Przypomniał, że jego poprzednik na urzędzie wielkiego mistrza, Fryderyk, nie złożył hołdu ani Zygmuntowi, ani jego poprzednikom. Po tym posłowie zaproponowali Albrechtowi złagodzenie przysięgi i kilku artykułów traktatu z 1466 r. Hohenzollern odrzucił również i te pomysły, zakon krzyżacki bowiem zubożał na skutek strat terytorialnych poniesionych w $1466 \mathrm{r}$. oraz podczas obecnej wojny i nie mógłby on np. dostarczać królowi środków na walkę z niewiernymi, o czym mówił jeden z punktów II pokoju. Uważał, że gdyby monarcha zwrócił Zakonowi wszystkie jego terytoria, wówczas wielki mistrz mógłby wspomóc króla w walce, a także w pełni realizować swoje zobowiązania. Posłowie zaproponowali, aby zgodził się na zawarcie na określony czas rozejmu z Zygmuntem i przekazanie sporu pod arbitraż Karola V i Ludwika Jagiellończyka. Albrecht wyraził na to zgodę pod warunkiem, że w czasie trwania rozejmu wszelka akcja zbrojna przeciw miastom i zamkom zostanie zaniechana, z pra-
} 
nymi, iż Albrecht Hohenzollern dwa dni wcześniej (28 marca) wyraził zgodę na zaproponowane warunki rozejmu. Wielki mistrz zgłosił jedynie zastrzeżenia do kilku artykułów (dotyczących składu i działania wybranych rozjemców oraz drogi powrotnej dla zaciężnych zakonu krzyżackiego do Rzeszy), w kwestii których pierwszego dnia kwietnia postanowiono się naradzić ${ }^{129}$. Co do powrotu wojsk do Rzeszy król zadecydował, że udadzą się tam one przez północną część kraju. Pozostałe postulaty wielkiego mistrza Zygmunt odrzucił. Dzień później, 31 marca, do dostojników negocjujących w Toruniu dołączył biskup pomezański Hiob Dobeneck. Potem rozpoczęto dyskusje w radzie królewskiej nad zwrotem okupowanych przez Krzyżaków posiadłości warmińskich. Król postanowił jednak odroczyć je w czasie. Wolał się skupić nad ustaleniem postępowania Królestwa Polskiego w wypadku nierozstrzygnięcia sporu z Zakonem przez arbitrów w czasie czteroletniego rozejmu. Monarcha postanowił, że jeśli konflikt nie zostanie rozwiązany, wojna będzie wznowiona i niezbędnym posunięciem będzie okrążenie Prus Krzyżackich ${ }^{130}$.

Dnia 3 kwietnia władca wraz z radcami królewskimi i pruskimi ustalili tekst rozejmu toruńskiego oraz drogi powrotnej zaciężnych Zakonu do Rzeszy. Zgodnie $\mathrm{z}$ treścią tego dokumentu zawieszenie broni pomiędzy stronami miało obowiązywać od 10 kwietnia $1521 \mathrm{r}$. do 10 kwietnia 1525 r. ${ }^{131}$ Dzień później w toruńskim ratuszu zorganizowano spotkanie króla z nuncjuszem papieskim Zachariaszem Ferreri i posłami cesarskimi oraz węgierskimi. Wtedy też odczytano artykuły kompromisu toruńskiego. Zostały one zaakceptowane przez wszystkich zebranych z wyjątkiem nuncjusza, który zgłosił protest z powodu pominięcia w tekście jego nazwiska. Dnia 5 kwietnia $1521 \mathrm{r}$. odbyło się spotkanie $\mathrm{w}$ podobnym składzie, dołączyli tylko przedstawiciele zakonu krzyżackiego, którzy po zapoznaniu się z treścią rozejmu rów-

wem zdobywania żywności przez obie strony konfliktu. Prosił również posłów o uzyskanie aprobaty polskiego władcy na jego propozycje - ibid., s. 112-113.

${ }^{129}$ Ibid., s. 115-116; J. Wijaczka, Albrecht von Brandenburg-Ansbach, s. 76.

${ }^{130}$ ASPK, t. 8, nr 18, s. 117.

${ }^{131}$ Ibid., s. 117-118; Die Danziger Chronik vom Bunde warscheinlich v. Peter Brambeck, s. 446-448; J. Wijaczka, Albrecht von Brandenburg-Ansbach, s. 76. 
nież go zaakceptowali ${ }^{132} .7$ kwietnia Albrecht Hohenzollern zgodził się na warunki zawieszenia broni, zaproponowane przez Zygmunta Starego i jego radców, i postanowił zawrzeć rozejm z polskim kró$1 \mathrm{em}^{133} .8$ kwietnia ukończono spisywanie treści dokumentu kompromisu. Został on wystawiony przez dwóch posłów cesarza Karola V oraz przez trzech dyplomatów Ludwika Jagiellończyka ${ }^{134}$. Następnie, prawdopodobnie w Ratuszu Staromiejskim, nastąpiło opieczętowanie dokumentów rozejmowych i ich wymiana przez obie strony konfliktu. Na koniec ustalono tekst deklaracji, która miała wyjaśniać wątpliwości interpretacyjne zawartego aktu ${ }^{135}$.

Po zakończeniu głównej sprawy, czyli zawarcia rozejmu, skupiono się na innych kwestiach. Jedną z nich było przedstawienie przez Polskę posłom cesarskim obaw z powodu gróźb wznowienia banicji cesarskiej na Gdańsk i Elbląg przez Sąd Kameralny Rzeszy ${ }^{136}$. Przedstawiciele cesarza zapewnili Zygmunta Starego, iż będą interweniować w tej sprawie u Karola V. Zależało na tym, jak się można domyślać, szczególnie posłom gdańskim, którzy jeszcze kilkakrotnie im o tym przypominali ${ }^{137}$.

${ }^{132}$ ASPK, t. 8, nr 18, s. 119-120; J. Wijaczka, Albrecht von Brandenburg-Ansbach, s. 76.

${ }^{133}$ Matricularum, pars 4, nr 3682.

${ }^{134}$ M. Biskup, „,Wojna Pruska”, s. 452; J. Wijaczka, Albrecht von BrandenburgAnsbach, s. 76.

${ }^{135}$ ASPK, t. 8, nr 18, s. 121-122.

${ }^{136}$ Konflikt ten rozpoczął się jeszcze w czasach panowania Jana Olbrachta. Król rzymski Maksymilian Habsburg, podobnie jak jego ojciec Fryderyk, akcentował roszczenia Rzeszy do Prus. Zależało mu zwłaszcza na sprawowaniu władzy nad Gdańskiem. Od czasu jednej z reform z 1485 r. przychodziły z Rzeszy do Gdańska różne wezwania, wśród których można wymienić między innymi rozkazy przyjazdów na sejmy niemieckie, nakazy podatkowe czy wysyłanie pozwów do stawienia się przed Trybunałem Rzeszy (Reichskammergericht). Wszystkie te listy gdańszczanie niezwłocznie przekazywali królowi. Ten był bardzo oburzony i stanowczo protestował przeciwko niepokojeniu jego poddanych. W 1497 r. zatarg ten zaostrzył się, gdy z powodu kolejnego niestawienia się władz Gdańska przed wspomnianym Trybunałem zapadł wyrok banicji i polecenia granicznym książętom atakowania kupców gdańskich - F. Papée, Jan Olbracht, Kraków 1999, wyd. 2, s. 177.

${ }^{137}$ ASPK, t. 8, nr 18, s. 120-121. 
Dnia 10 kwietnia nastąpiło uroczyste pożegnanie poselstw przez Zygmunta I. Przemówienie z tej okazji król Polski wygłosił w języku łacińskim. Nawiązywał w nim między innymi do sprawy małżeństw Jagiellonów z Habsburgami czy niedawnych narodzin jego syna Zygmunta Augusta. Następnie podziękował dyplomatom za podjęte przez nich wysiłki, które doprowadziły ostatecznie do zawieszenia działań wojennych i przekazania sporu z wielkim mistrzem Albrechtem Hohenzollernem pod arbitraż międzynarodowy. Po wysłuchaniu tej mowy posłowie opuścili miasto ${ }^{138}$.

Po zawarciu rozejmu i wyjeździe zagranicznych delegacji monarcha pozostał $\mathrm{w}$ Toruniu jeszcze przez kilkanaście dni w celu uporządkowania, przy współudziale tamtejszych organów samorządowych, spraw pruskich. Dnia 11 kwietnia biskup Dobeneck zwrócił się do władcy z prośbą, aby ten ze względu na ubóstwo podległego mu kościoła oddał okupowane zamki i miasta. Przy okazji złożył jeszcze skargi na wykroczenia Stanisława Kostki. Król postanowił nieco wspomóc biskupstwo i zgodził się na zwrot dwóch zabranych mu miasteczek ${ }^{139}$.

Dzień później (12 kwietnia) podczas audiencji w Ratuszu Staromiejskim z prośbami do władcy zwrócili się radcy pruscy. Prosili go, aby nie opuszczał Prus, tylko udał się na północ państwa w celu zaprowadzenia tam spokoju, a także, by król pozostawił w Prusach dla bezpieczeństwa około 200-300 ze swoich zbrojnych konnych. $\mathrm{Na}$ koniec proszono, aby monarcha doprowadził do szybkiego zwrotu posiadłości biskupstwu warmińskiemu ${ }^{140}$. Zygmunt udzielił odpowiedzi po dwóch dniach (14 kwietnia). Król stwierdzał, iż musi wracać do Korony między innymi w celu przeobrażenia 4-letniego rozejmu z Zakonem w trwały pokój. Wśród innych powodów wymienił konieczność spłacenia należności zaciężnym i przede wszystkim chęć zobaczenia swojego nowo narodzonego syna Zygmunta Augusta. Zapewnił jednak o zamiarze jak najszybszego powrotu do Prus Królewskich i zaprowadzenia tu ładu wewnętrznego. Na koniec stwierdził, iż do czasu wyjazdu (a planował pozostać jeszcze około 8-14 dni) może załatwić

\footnotetext{
${ }^{138}$ Ibid., s. 122-123.

${ }^{139}$ Ibid., s. 124-125.

${ }^{140}$ Ibid., s. 124-126.
} 
drobniejsze sprawy. Dodał, że kwestie warmińskie będą musiały poczekać na rozstrzygnięcie i zostaną przez niego rozpatrzone później ${ }^{141}$. Tego samego dnia (14 kwietnia) w Toruniu Zygmunt I, na prośbę wojewody malborskiego i starosty gniewskiego Jerzego Bażyńskiego, potwierdził dokonanie zastawu wsi Wybcz przez wojewodę chełmińskiego Gabriela Bażyńskiego na rzecz mieszczanina toruńskiego Hermana Pape za kwotę 60 florenów węgierskich ${ }^{142}$.

Dnia 16 kwietnia odbyła się w ratuszu osobna narada radców pruskich. Debatowano nad głównymi problemami kraju, które będą poruszone podczas rozmów z królem, i skarg, które miały być u niego złożone. Dostojnicy pruscy postanowili, że zredagują dla władcy specjalny ich wykaz ${ }^{143}$. Zanim jednak go sporządzono, rozpatrywano najpierw sprawy nadużyć rzemieślników miejskich i wykupywania zboża na wsi, a później propozycję arcybiskupa Łaskiego dotyczącą podjęcia wspólnych obrad rady koronnej i rady pruskiej. Dnia 18 kwietnia rada pruska zdecydowanie odrzuciła tę propozycję i prosiła króla o to, aby odbył z nią odrębne rozmowy. Władca miał zastrzeżenia co do tego pomysłu, lecz z powodu uporu radców ostatecznie przystał na ich prośby. Spotkanie to nastąpiło dzień później, czyli 19 kwietnia. Na obrady z królem miano dostarczyć przywilej inkorporacyjny Prus z 1454 r. z Archiwum Ziem Pruskich, który wraz z innymi przywilejami władca miał potwierdzić ${ }^{144}$. Podczas spotkania przedstawiono również królowi wcześniej przygotowany wykaz skarg. Debaty na temat poszczególnych punktów były prowadzone przez kilka dni ${ }^{145}$.

W poniedziałek 22 kwietnia król postanowił wybrać się do miejscowego sanktuarium w Barbarce, położonej jedną milę za Toruniem. Towarzyszył mu niewielki orszak. Król miał tam „wytrwać” 9 dzwonów [godzin?]. Być może było to dla niego wyczerpujące, gdyż naza-

${ }^{141}$ Ibid., s. 127-129.

${ }^{142}$ Katalog dokumentów, nr 231.

${ }^{143}$ ASPK, t. 8, nr 18, s. 130

${ }^{144}$ M. Biskup, U schyłku średniowiecza, s. 185. Chociaż w Inwentarzu Metryki Koronnej figuruje inna data konfirmacji przywilejów pruskich, a mianowicie 12 kwietnia - Matricularum, pars 4, nr 3694.

${ }^{145}$ Wykaz skarg oraz szczegóły prowadzonych rozmów można znaleźć w ASPK, t. 8 , nr 18, s. 131-146. 
jutrz nie wziął udziału w żadnym spotkaniu z panami koronnymi i pruskimi ${ }^{146}$. Po dwudniowej przerwie władca uczestniczył w kolejnych dyskusjach z przedstawicielami stanów pruskich. Dnia 24 kwietnia radcy złożyli u niego skargę na samowolne zamykanie żeglugi przez Gdańsk. Prosili, aby wpłynął na zaniechanie tego procederu. Następnie złożyli kolejną skargę, tym razem na pobieranie cła funtowego w porcie gdańskim wyłącznie do kasy miasta ${ }^{147}$. Z kolei przedstawiciele Torunia żalili się z powodu zakazywania ich kupcom przeładunku zboża bezpośrednio na statki w porcie gdańskim ${ }^{148}$. Na koniec gdański burmistrz przedstawił wysokie wydatki, jakie poniosło miasto w ostatniej wojnie. Spowodowały one zadłużenie Rady. W związku z tym prosił Zygmunta Starego o pomoc finansową. Rozwiązanie tej i wcześniej wspomnianych spraw król odroczył jednak do czasu lipcowego zjazdu grudziądzkiego ${ }^{149}$.

Monarcha w czasie pobytu $\mathrm{w}$ Toruniu zajmował się jeszcze skargą złożoną mu przez prokuratora krzyżackiego z Nidzicy Henryka von Miltitza na bezprawia, jakiego dopuszczali się urzędnicy królewscy wobec wielkiego mistrza i Zakonu. Dla zachowania układu rozejmowego władca wyznaczył radców i komisarzy, którzy w lipcu $1521 \mathrm{r}$. mieli na zjeździe w Grudziądzu spotkać się z posłami krzyżackimi w celu uregulowania tych zatargów ${ }^{150}$.

Podczas pobytu w Toruniu (12 kwietnia) Zygmunt Stary wydał jeszcze na prośbę radców konstytucje - statuty i ordynacje dla Prus Królewskich („Statuta et ordinationes terrarum Prussiae”). Wszyscy wojewodowie mieli przesłać powyższe konstytucje starostom i władzom miast pruskich pod pieczęcią wojewodzińską. $\mathrm{Z}$ ich treścią mieli również

\footnotetext{
146 „Am montage vor Georgii, das ist post Iubilate [22 IV 1521] ist die Ko.Ma. mit etczlichen seynen reten und hovegesynde zu Sanct Barberen, eyne meyle weges von Torun gelegen, geritten und aldo byss uber die glocke 9 beharret, also das dess morgendes keyn raet ader // handel gewest ist, besunder die herren van Landen und Stetten seynt bey dem herren van der Loebe gewest ut sequitur" - ibid., nr 18, s. 143; M. Biskup, Uschytku średniowiecza, s. 186.

${ }^{147}$ ASPK, t. 8, nr 18, s. 143-144.

${ }^{148}$ Ibid., s. 143-146.

${ }^{149}$ Ibid., s. 137-138.

150 Jednak nie wiadomo, czy zgłaszane sporne kwestie zostały rozwiązane, gdyż z relacji z lipcowego zjazdu wynika, że spraw tych na nim nie poruszano - ibid., s. 146.
} 
zaznajomić szlachtę i pozostałych poddanych. Za nieprzestrzeganie konstytucji groziły kary ${ }^{151}$.

Dnia 25 kwietnia odbyła się w toruńskim ratuszu pożegnalna audiencja u polskiego króla, podczas której nuncjusz papieski Zachariasz Ferreri podziękował władcy za doprowadzenie do rozejmu z wielkim mistrzem. Dzień później, po 17-miesięcznym pobycie w Toruniu, monarcha opuścił miasto i udał się przez Brześć Kujawski do swojej siedziby w Krakowie ${ }^{152}$.

\section{Zakończenie}

Dzięki sporej ilości zachowanych źródeł możliwe jest dość dokładne przedstawienie najważniejszych szczegółów wizyt króla Zygmunta Starego w Toruniu, ich dokładnej chronologii oraz przyczyn ich odbywania. Pozwalają one również ustalić grono osób towarzyszących w podróżach jagiellońskiemu władcy. Byli wśród nich dostojnicy duchowni i świeccy oraz oddziały wojsk nadwornych (a w czasie prowadzenia działań wojennych również oddziały zaciężne).

Zachowane źródła umożliwiają także przynajmniej częściowe umiejscowienie toruńskich wizyt Zygmunta Starego w ówczesnej topografii miasta. $Z$ zaprezentowanych ustaleń wynika, że monarcha miał w zwyczaju obieranie sobie Ratusza Staromiejskiego za rezydencję, w której mieszkał w czasie swoich pobytów w Toruniu. Natomiast królewscy dostojnicy i przedstawiciele poszczególnych poselstw (polskich, pruskich oraz zagranicznych), jak też sami wielcy mistrzowie Zakonu lokowani byli w miejscowych gospodach lub w klasztorach. Obrady i audiencje, w czasie których król spotykał się z przybyłymi delegacjami, także odbywały się najczęściej w toruńskim ratuszu. Poza tym polski władca brał udział w nabożeństwach w kościele Świętych Janów. Msze były bowiem nieodłącznym elementem królewskich wizyt i świętowania ważniejszych wydarzeń, na przykład narodzin syna monarchy - Zygmunta Augusta w sierpniu 1520 r.

\footnotetext{
${ }^{151}$ Ibid., nr 17, s. 97.

${ }^{152}$ M. Biskup, ,,Wojna Pruska”, s. 457-458.
} 
Efektem stosunkowo częstych i długich pobytów Zygmunta Starego w Toruniu był wzrost znaczenia miasta, które, niezależnie od tego, że było już ważnym ośrodkiem gospodarczym, społecznym i kościelnym, z racji napiętej sytuacji w stosunkach Polski z państwem krzyżackim urastało również do rangi jednego $\mathrm{z}$ ważniejszych centrów politycznych w skali całej monarchii. To tutaj bowiem, na pograniczu Kujaw i ziemi chełmińskiej, król przebywał przez dłuższy czas zarówno w trakcie prowadzenia negocjacji politycznych (nie tylko ze stroną krzyżacką), jak i działań wojennych zakończonych zawarciem rozejmu. W trakcie swoich pobytów w Toruniu Zygmunt Stary porządkował liczne sprawy pruskie, ale nie tracił z pola widzenia innych istotnych problemów polityki wewnętrznej i międzynarodowej. $Z$ drugiej strony warto również wziąć pod uwagę inny aspekt pobytów monarchy w Toruniu, a mianowicie koszty, które $\mathrm{z}$ tego tytułu ponosiło miasto. Zagadnienie to wymaga jednak przeprowadzenia osobnych badań.

\section{Sigismund the Old's visits in Torun (1519-1521)}

The aim of the article is to show Sigismund the Old's visits in Torun in the years 1519-1521 during the last Polish-Teutonic war. It was Torun that constituted the main seat of the Polish monarch during the military conflict mentioned above.

Owing to a significant number of preserved sources it was possible present thoroughly the most important details of Sigismund the Old's visits in Torun, their exact chronology and people who accompanied the monarch.

The article was divided into four parts. In the first part the author concentrates on Sigismund the Old's participation in the general Sejm in Torun. The main subject matter of the assembly was the question of the possible military struggle with the Teutonic Order. The second part of the article describes the participation of the Polish monarch in the Second Assembly of the Prussian Estates (13-30 May 1520). The main topic of the meeting was the problem of peaceful attempts to finish the Polish-Teutonic conflict. The third part focuses on the first stage of the peace negotiations (the summer of 1520), while the fourth part - on the continuation of the war and the second stage of the peace negotiations (the summer 1520 - 25 April 1521). 


\section{Die Besuche Sigismunds des Alten in Thorn (1519-1521)}

Ziel des Artikels ist die Darstellung der Besuche von König Sigismund dem Alten aus der Jagiellonendynastie in Thorn in den Jahren 1519-1521, während des letzten Krieges zwischen Polen und dem Deutschen Orden. Denn Thorn war der Hauptsitz des polnischen Herrschers zur Zeit dieses bewaffneten Konflikts.

Eine beachtliche Menge von erhaltenen Quellen macht es möglich, die wichtigsten Details der Besuche von Sigismund dem Alten in der Stadt recht genau darzustellen und ihre Chronologie und die den Monarchen begleitenden Personen zu ermitteln.

Der Artikel gliedert sich in vier Teile. Im ersten geht es um die Teilnahme von Sigismund dem Alten am Reichstag, der in Thorn stattfand. Der Hauptgegenstand der Beratungen war die Frage eines eventuellen Waffengangs mit dem Deutschen Orden. Der zweite Teil des Artikels beschreibt die Teilnahme des polnischen Monarchen an der zweiten Zusammenkunft der preußischen Stände (13.-30. Mai 1520). Hauptthema des Treffens waren Versuche, den Konflikt zwischen Polen und dem Deutschen Orden friedlich zu beenden. Im dritten Punkt geht es um den ersten Teil der Friedensverhandlungen (Sommer 1520) und im vierten um die Fortsetzung des Kriegs und den zweiten Teil der Friedensverhandlungen (Sommer 1520 bis 25. April 1521). 